DEVELOPING WORD WALL AS MEDIA IN TEACHING WRITING SKILLS ON DESCRIPTIVE TEXT FOR THE SEVENTH GRADE STUDENTS AT SMP YPI AMIR HAMZAH MEDAN

\begin{abstract}
AN ARTICLE
Submitted in Partial Fulfillment of the Requirements for the Degree of Sarjana Pendidikan
\end{abstract}

ADE RISKA DAMAYANTI

Registration Number: 2151121002

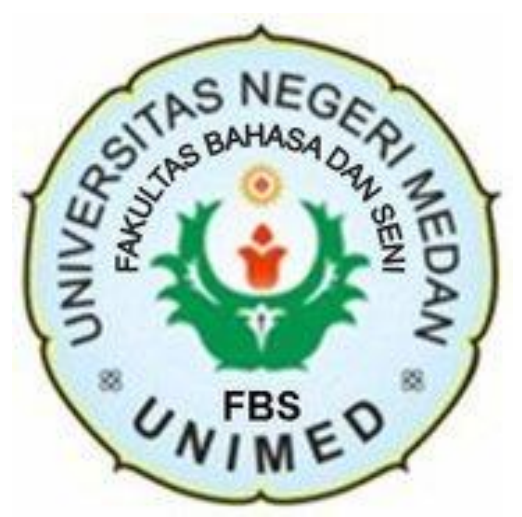

ENGLISH AND LITERATURE DEPARTMENT

FACULTY OF LANGUAGES AND ARTS

UNIVERSITAS NEGERI MEDAN

2020 


\title{
DEVELOPING WORD WALL AS MEDIA IN TEACHING WRITING SKILLS ON DESCRIPTIVE TEXT FOR THE SEVENTH GRADE STUDENTS AT SMP YPI AMIR HAMZAH MEDAN
}

\author{
*Ade Riska Damayanti \\ **Dr. Masitowarni Siregar, M.Ed. \\ **Puan Suri MiraAnnisa Sembiring, S.Pd., M.Hum.
}

\begin{abstract}
S
Damayanti. Ade Riska. Registration Number: 2151121002. Developing Word Wall as Media in Teaching Writing Skills on Descriptive Text for The Seventh Grade Students at Smp Ypi Amir Hamzah Medan. English Education Program, Universitas Negeri Medan, 2019.

The study was aimed to to develop learning media in Writing Descriptive Text for Grade VII of Junior High School Students. This study was conducted by using Research and Development (R\&D) design through six stages; gathering information and data, analyzing data, designing materials, validating by experts, revising, and final product. The subject of the study was Grade VII of SMP Ypi Amir Hamzah Medan. The instruments of data collection were gathered by administring interview and distributing questionnaire. The study conducted interview to the English teacher and distributing questionnaire to 25 respondents to get the students' needs. The interview and questionnaire results proved that the students need English learning media which can motivate the students to understand about writing descriptive text. The product had been validated by the experts namely English lecturer and English teacher. The product result was Word Wall which is modifying House based on destination of North Sumatera. The result of experts' validation showed that the media was an appropriate media to be used on writing descriptive text by getting the average percentage $92 \%$ categorized excellent.
\end{abstract}

Keywords: Writing, Descriptive Text, Word Wall, Research and Development

\footnotetext{
*Graduate Status

***ecturer Status
} 


\section{INTRODUCTION}

\section{Background of the Study}

Writing is also an excellent communication tool. Through writing, each person will be able to convey feelings, ideas, and announcement to others. Brown (2001) states that the writing is a process of putting ideas down on paper to transform thoughts into words to sharpen main idea to give structure and koherent organization into its work. Nadeem, et.all (2016) stated that writing has often been considered equal to teaching grammar and sentences structure. Then different surveys proved that writing is difficult and a complex process. Though writing is a difficult part, but the students should master that skill since it is essential in learning English. There are some kinds of genre in English. Then according to syllabus of curriculum 2013, one of the genres students learnt in Junior High School is descriptivr text. A Descrivtive text is describe aboutsomething such as person, animal,person and place.

However, the students ability of writing descriptive text was still lack showed from the students' score which was still under the minimum score (KKM) of the eighth grade at SMP Ypi Amir Hamzah Medan (KKM=70).

In teaching and learning process, it was found some problems including the students' attitude. The students tended to be bored in learning English such as in writing descriptive text. The students were also lack of motivation since they were not interested in the teaching and learning process because of the unchangable method from the teacher. The researcher found earlier that the teacher used lecturing method. Another problem is students did not understand what the teacher had explained. In addition, there was no media used since the teacher only taught descriptive text then asked the students to write a descriptive text whereas the students were still confused what actually descriptive text is and how to write it.

Based on the students' attitude which are easy to be bored and the purpose of curriculum 2013 that also demand the students as future generations, should know about their local wisdom. Green (1993) argued that word walls is an organized collection of large print words on the classroom wall. A word wall help 
to create a print rich environment for students, and can be a wonderful tool that is designed to promote group learning.

The word wall will also make the students to be easier in learning since they will learn based on their environment itself. Since even the students learn English as a foreign language, the students still are educated based on their identity. Ningrum (2015) stated that "Education sees the environment as a source of knowledge for the formation of word wall.

In this case word wall, an interesting useful application for students, comes up as a solution in helping the teacher to achieve the goal of the writing skill. Word wall is a game which is the result of modifying house. It will consist of some elements that relate to local wisdom of North Sumatera.

Therefore, the study was aimed to develop word wall as a English teaching on writing descriptive text for the $7^{\text {th }}$ grade students at SMP Ypi Amir Hamzah Medan.

\section{REVIEW OF LITERATURE}

\section{Writing}

Writing is one of language skills which should be mastered by the students. In writing, there will be product which is written form since the students will deliver the ideas, thoughts, and experiences. Therefore, the students should be able to write well in order to express their feeling, need, and desire in a understandable written form.

Harmer (2004: 7) stated that writing is the only skill that can produce a real product, which is touchable, readable, and keepable for long time. Since the speaking skill that can produce the spoken form of language is only heard without any real form.

Harmer (2004: 4-5) gives four main steps that the writer should pay attention to, there are planning, drafting, editing (reflecting and revising) and final version. The details of each steps can be described such as, (1) Planning, (2) Drafting, (3) Editing (Reflecting and Revising), (4) Final Version. 


\section{Descriptive Text}

Zemach and Rumisek (2005), stated that descriptive paragraph explain how someone or something looks or feels. The process of paragraph exlpain how something is done. Descriptive paragraph describe about a person, a place, or a thing in which descriptive paragraph has three generic structures such as identification, description, and conclusion.

A descriptive text is a piece of writing that is intended to convey meaning to the reader through sensory details and provide image to the reader. Additionally, descriptive text is a paragraph may be defined as a group of sentences that are closely related in though and which serve one comment purpose often used to describe what a person looks and acts like, what a place looks like, and what an object like. Futhermore, Pardiyono (2007) state that description paragraph is a type of written text paragraph, in which has the spesific function to describe about an object and it has the aim that is giving description of the object to the reader clearly.

\section{Media}

Kamaludin (2009) states that media is facilities, resources or tools used by people to produce message or information. It can be any components that students used to convey messages in order to build their motivation to learn. Media is a tool to support teaching and learning process. Media will increase the learning motivation and curiosity of the students. In Willingham's (2009) research, he asked a simple question to make his point, "Why do students remember everything that's on television and forget what we lecture?" -because visual media helps students retain concepts and ideas. Sudjana (2001: 64) metions the function of learning media in teaching - learning process such as, (1) It is not addition function, but has own function as an aid to express effective teaching learning situation; (2) It is integral part of all learning situation; and (3) The using of learning media is more important to accelerate 
teaching and learning process and help student in comprehend material from teacher.

\section{RESEARCH METHODOLOGY}

This research was conducted by using educational Research and Development (R \& D) by Borg and Gall (2003). This sudy was conducted at SMP Ypi Amir Hamzah Medan which is located in Jl. Meranti No 1 Medan Petisah, Medan Sumatera Utara. The subject of this study is the grade VII students of SMP Ypi Amir Hamzah Medan. The instruments of data collection were gathered by administring interview and distributing questionnaire. The study conducted interview to the English teacher and distributing questionnaire to 25 respondents to get the students' needs. In addition, the qualitative and quantitative research were conducted to analyze the data.

\section{RESEARCH FINDING AND DISCUSSION}

Research findings

This study was aimed to create a learning media based on the students and also the teacher needs. The researcher used Recycle material modification called as word wall. The learning media that made by the researcher done in several steps. The step planning consists of preparing the material, designing the media, making media, adding some decoration to make media more interesting.

The learning media created by using word wall has the result that the students and the teacher want for. The learning media consists of descriptive text materials, information about meaning of descriptive text, some picture of places in North Sumatera, and the tasks in writing descriptive text. The media is completed by some equipments of word wall.

\section{a. The Equipments of Word Wall}

In designing the word wall used the recycle material such as cartoon. Then the researcher design the word wall by shaping the cartoon becoming house form 


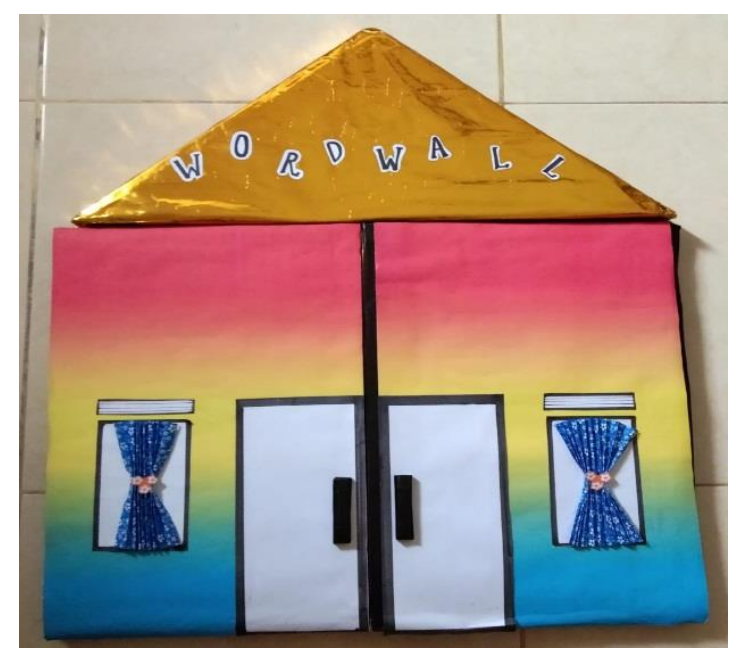

Figure 4.1 Word Wall

Furthermore, the equipments were needed in completing Word Wall such as cards, deeds. Then the researcher designed the cards consisting four kinds of cards. All the cards were designed by using Microsoft word Application in laptop. Those cards are shown the figure below.
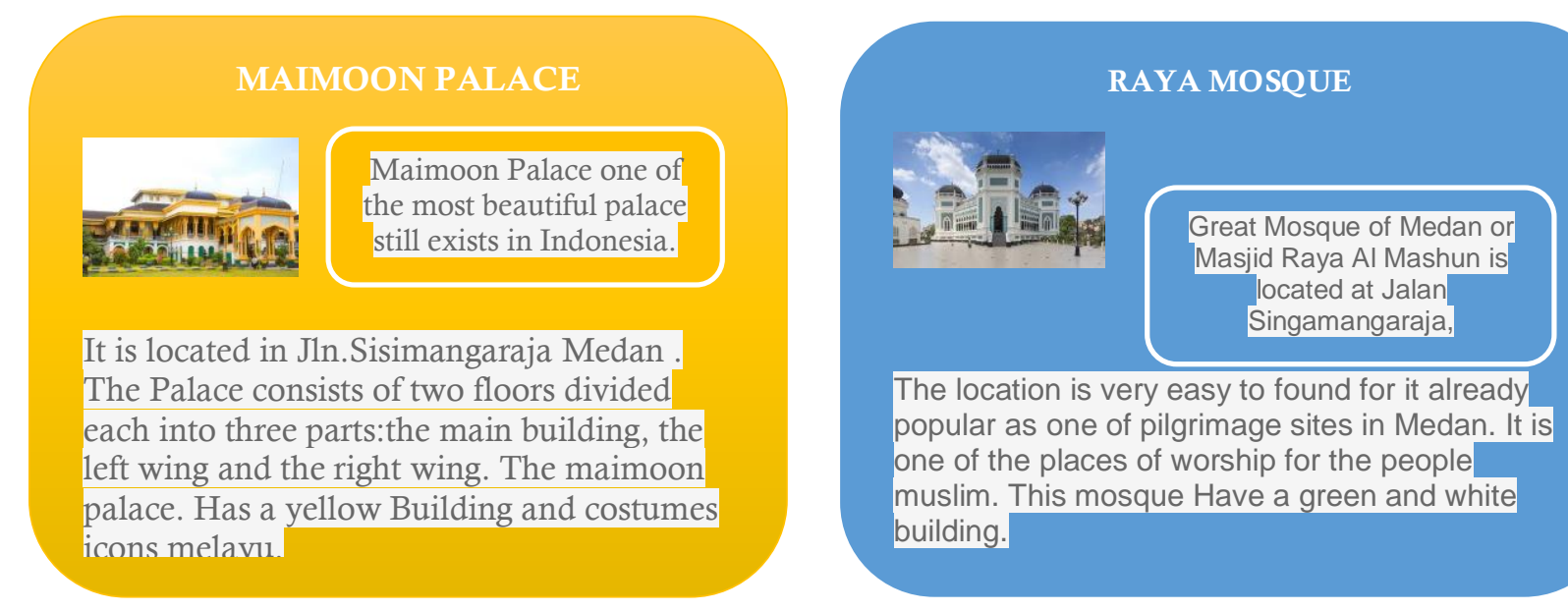

The location is very easy to found for it already popular as one of pilgrimage sites in Medan. It is one of the places of worship for the people muslim. This mosque Have a green and white building.
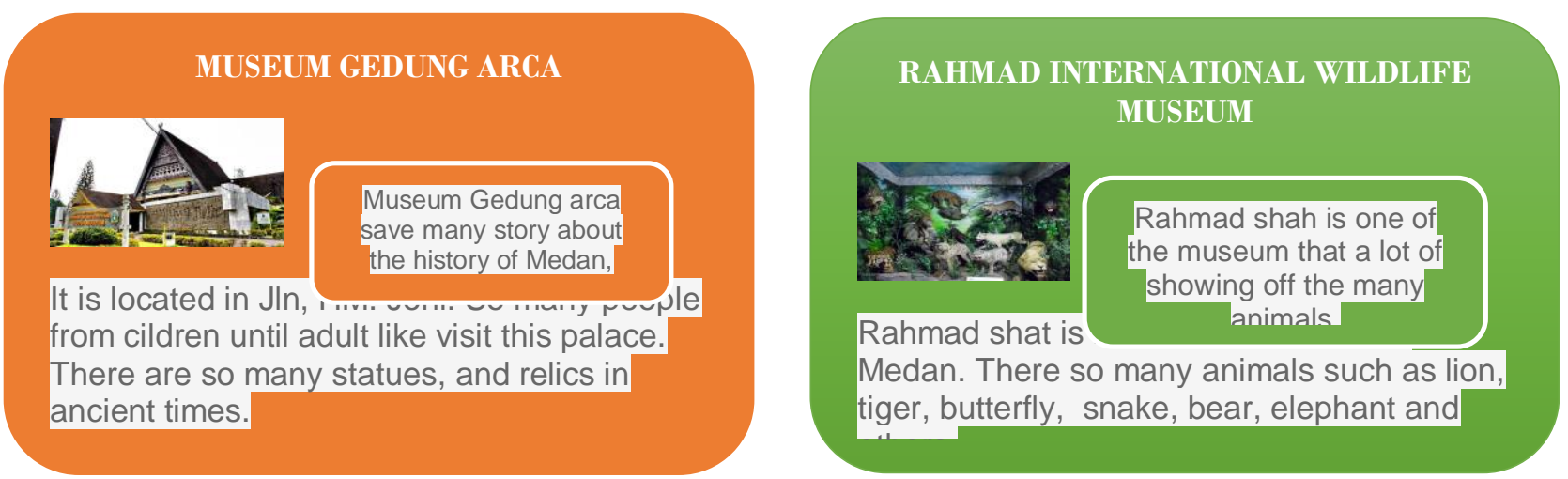

Figure 4.2 Cards of Word Wall 
Furthermore, in playing word wall, it is needed a dice to determine the picture by the group. Therefore, the researcher designed the interesting dice manually by recycling used cardboard. The dice and its media are shown as the figure below.

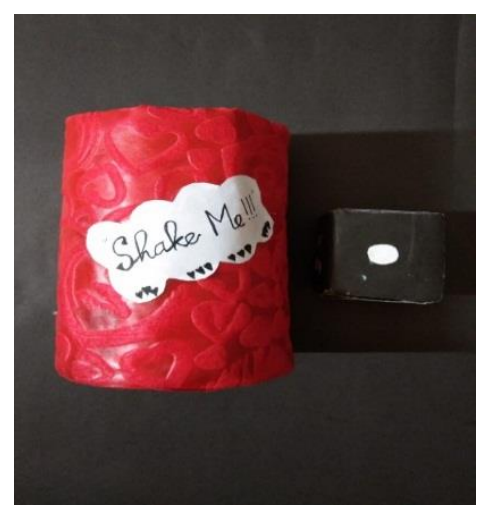

Figure 4.3 The Dice of Word Wall

The players will not know how to play Word Wall well. Therefore, the researcher made a manual book containing the information of Word Wall such as introduction, the equipments, the general rules, the specific rules, the procedures, and the ways to be a winner. The template of manual book is shown as figure 4.4.

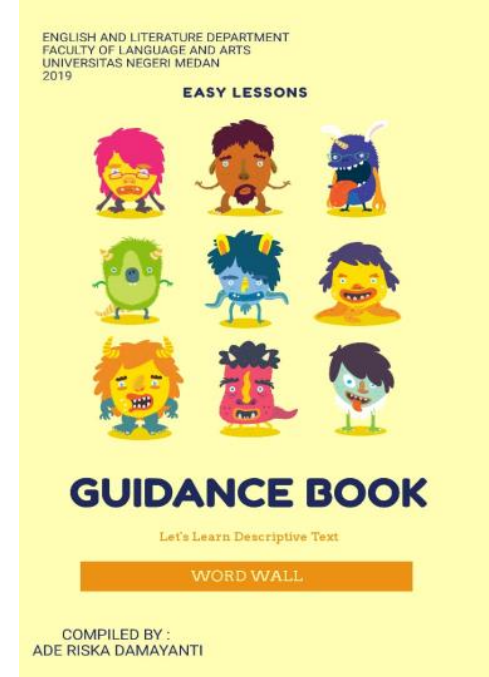

Figure 4.4 The Guidance Book of Word Wall

\section{b. Word Wall Media}

Word Wall was designed manually by using recycle materials that were added some accessories to make media more interesting. The concept of board media was like a house that icreases the students curiosity toward the Word Wall. 
Thus, there is difference from between exterior and interior Word Wall. The figures 4.5 below shows the exterior of word wall.

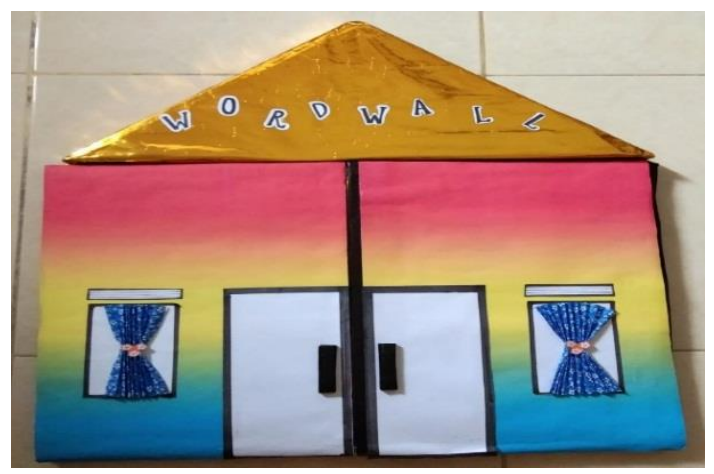

Figure. 4.5 Exterior of Word Wall

After opening the house, the Word Wall display becomes flats as board call interior of Word Wall. It has a board card, deed, and picture. It can attract the students' interest by the right color combination. The interior of Word Wall is shown as the figure 4.6 below.
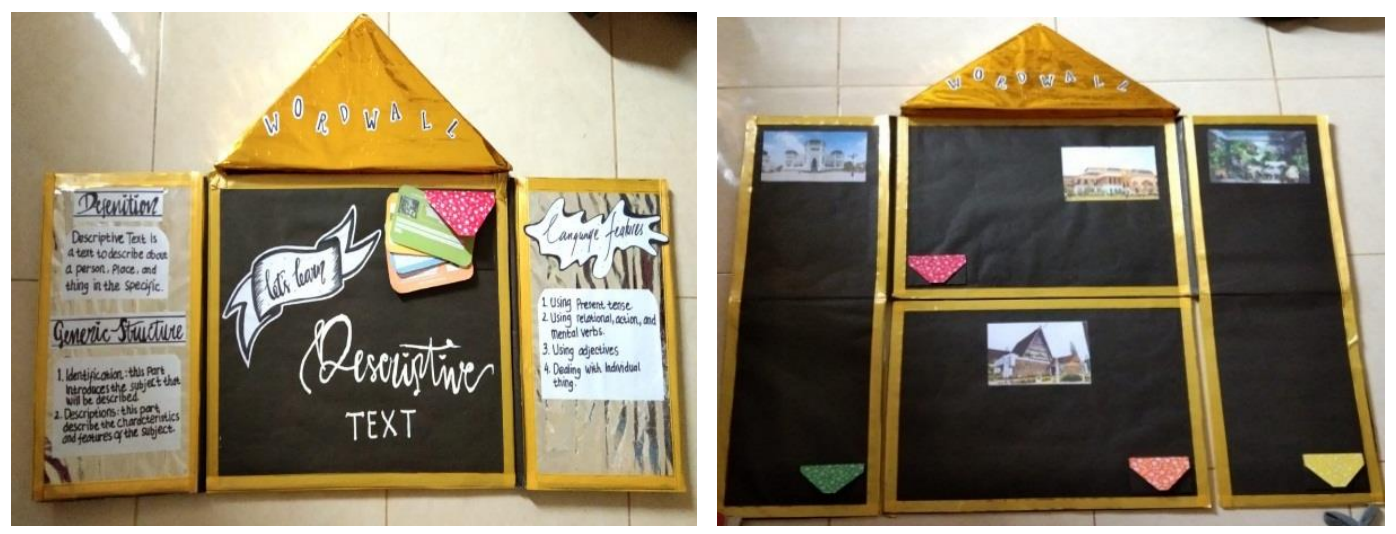

Figure. 4.6 Interior of Word Wall

In order to implement the curriculum of 2013 that applied scientific approach, Sani (2015:53) stated that Scientific Approach can be done in the following steps:observing, questioning, experimenting, associating and communicating. The scientific approach relates to the Word Wall on writing descriptive text especially personal descriptive text since in doing the task by the group, the students were directed to follow the steps of scientific approach which are explained below. 
1) Observing

The first step of scientific approach was observing. In this step, the teacher shows Word Wall showed the figure 4.7 below in front of the class
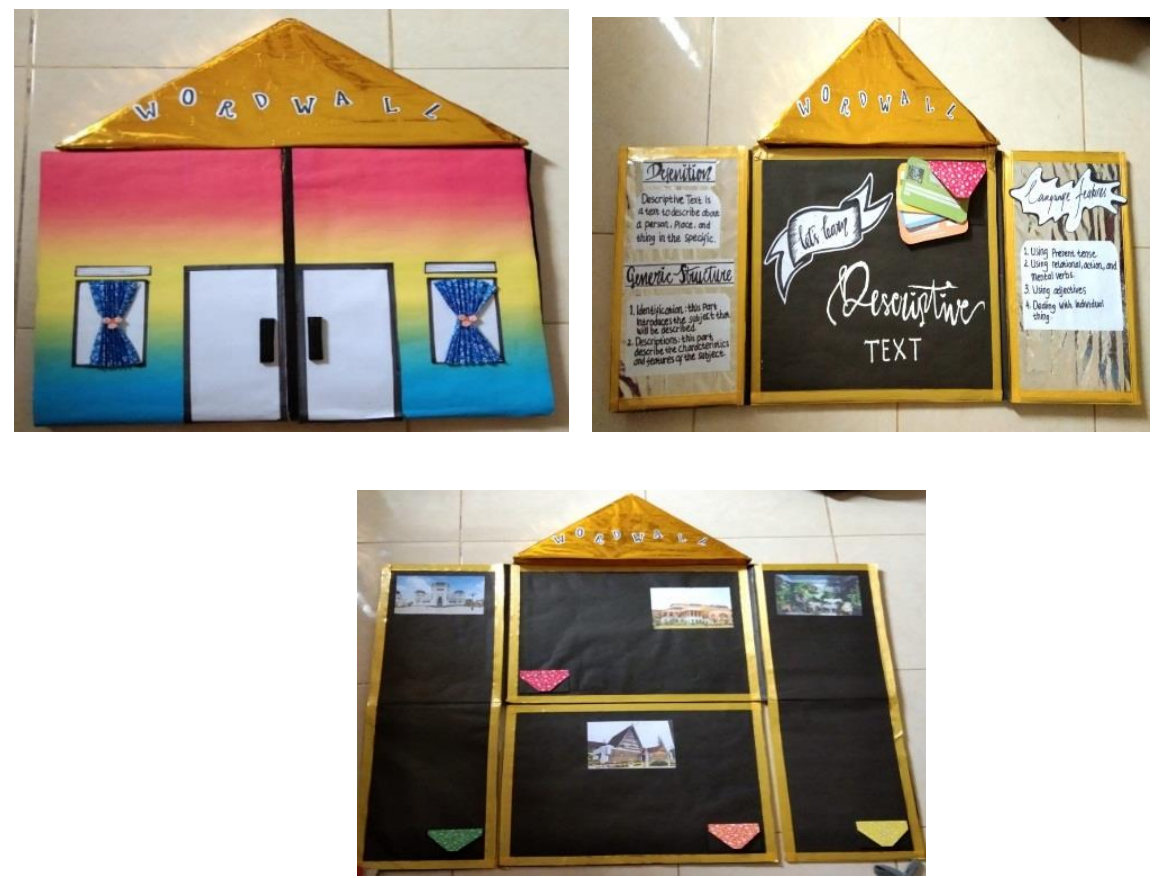

Figures 4.7 Word Wall

Then, the students will look at a house that can be opened, then becoming the explanation and taks from subject namely descriptive text. The students will be directed to see the interior from the house. Then, they will be asked to remember bout the descriptive text such as about the places, the teacher will give the explanation about the subject namely descriptive text and after that the teacher will ask the students tomake a group and doing the taks based on the groups. Furthermore, the students read the manual book containing all the information about Word Wall as the instruction or rules of the taks to stimulate the students to think on how to write descriptive text based on word wall which relates to some interesting places in North Sumatera, especially Medan.

\section{2) Questioning}

The next step was questioning. In this step, the students were supposed to ask questions related to the instruction or rules in playing the Word Wall. 
Not only that,but the students are also supposed to ask about how to write personal descriptive text relating toward the look at the picture inside. The question have also include in the word wall to stimulate the students about how to write descriptive text. Furthermore, the questions in word wall will direct the students to be more curiosity in knowing about personal descriptive text which is the characteristics of the places. Here are the questions example which make the students to be more curiosity about the media Word Wall.

1. As a youth generation, how to write your short personal descriptive text about the characteristics of places?

\section{3) Associating}

The next steps was accociating. The teacher divides the class into some groups. Each groups discuss the ideas of descriptive text in general related to the word wall intructions in writing descriptive text.

In this step, the students start to play the Word Wall from the first open the house. Then the students see the explanation and information of the descriptive text expecially about the defenition, generic structure and also the language features from the descriptive text. After the students know the explain from the subject, the teacher will opened again, and the students will see the picture inside. The students will take the word in the pocked and should arrange the word based o the picture. The figure 4.8 below shown Word Wall as a playing borad of the students.
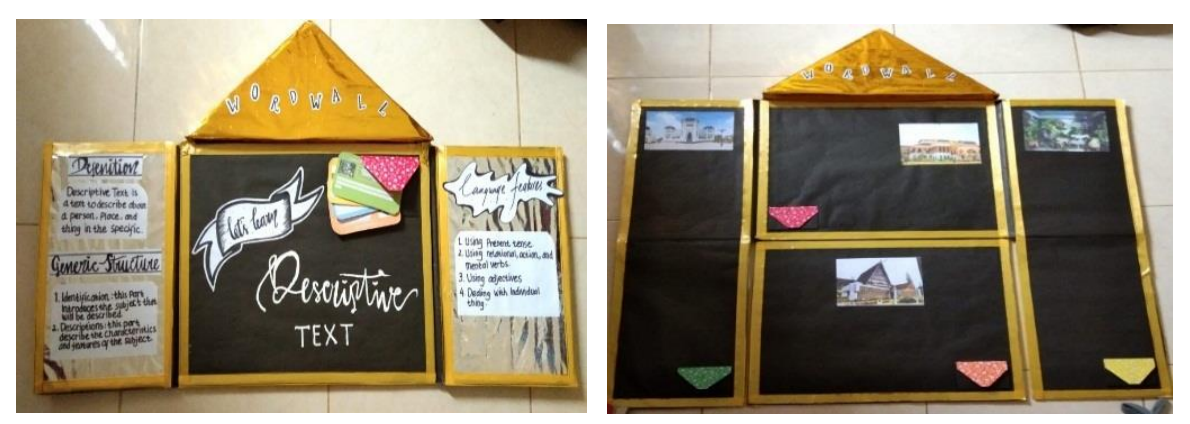

Figures. 4.8 explanation and taks of descriptive text 


\section{4) Experimenting}

The students play the word wall. The students attempt to write descriptive text based on the instruction given. The players will be asked to write descriptive text when the players get number from the picture. Then the players must discuss with the group to arrange the word from the pocked based on the instructuions which almost asked to write personal descriptive text about places in North Sumatera especially in Medan. To be the winner each of groups should fast to finished the word as well. If the group can finished the game as well so the group can be the winner in this section.

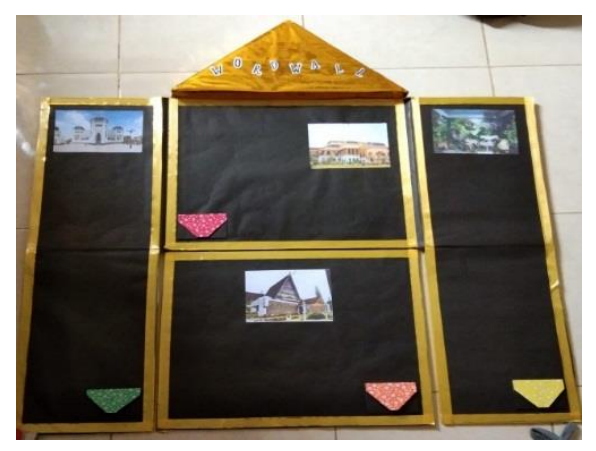

Figures. 4.9 Word Wall

\section{5) Communicating}

The Last Step is communicating. Communicating is the step to show the results of the students in writing descriptive text in the class. In this step, the teacher guided the students to show the results about personal descriptive text and also did dome corrections to the students.for example, the teacher can summing up some difficult vocabulary that they can be memorized later and asking to tell about the places information that the students found while playing Word Wall. Then, the other players have also suppsed knowing descriptive text. the winner of Word Wall will be determined the results from the each of group when the students are able to describe their place by arranging the words correctly and when the students arrange the description faster than others. Therefore, by implementing scientific approach relating to Word Wall makes the players which 
are the students became understandable about descriptive text and had ability in writing descriptive text well.

Table 4.9. The Result Data of Experts' Validation of Word Wall

\begin{tabular}{cccc}
\hline No & Item Assessed & $\begin{array}{c}\text { Experts Validation } \\
\text { (Percentages) }\end{array}$ & Criteria \\
\hline 1 & Linguistic Aspect & 85,7 & Good \\
\hline 2 & Process Aspect & 100 & Excellent \\
\hline No & Item Assessed & Experts Validation & Criteria \\
& & (Percentages) & \\
\hline 3 & Product and Content Aspect & 90 & Excellent \\
\hline 4 & Layout Aspect & 94 & Excellent \\
\hline & An overall assesment & & Excellent \\
\hline
\end{tabular}

\section{Discussion}

The result of this study is to develop a learning media and to find out the needs for the seventh grade students. The researcher developed the learning media because the media is not appropriate for the seventh grade students at SMP Ypi Amir Hamzah Medan. The media contains of main competence and basic competence as the basis and are believed to be able to ease the students in ability in writing descriptive text especially personal descriptive text.

The experts had validated media which is categorized excellent. Since the average percentages of those aspects is $92 \%$. In general, the experts' validation is excellent even there are also some aspects which are good. However, overall the word wall has fulfilled some standards and students' need on writing descriptive text for the eighth grade students at SMP Ypi Amir Hamzah Medan. There are only few things that should be improved such as language efficiency, discussion 
process, and unknown vocabularies which are categorized good by both of experts.

\title{
CONCLUSIONS AND SUGGESTIONS
}

\author{
Conclusions
}

After analyzing the data gotten from interview and questionnaires results of English teacher and students at SMP Ypi Amir Hamzah Medan, the researcher draws the conclusion that the students are lack of motivation since they are not interested in the teaching and learning process. Furthermore, after conducted the study, the result of the study showed that the average percentage of validation from the experts is $92 \%$ and it is categorized as relevant. It means that the media are valid and appropriate to use as learning media of writing descriptive text for the eighth grade students at SMP Ypi Amir Hamzah Medan.

\section{Suggestion}

1. For the teacher should find an appropriate learning media in improving their skill and motivating them in learning English.

2. For the students, they can use the Word Wall as a media for them to be used in writing recount text.

\section{REFERENCES}

Anggraini, 2010. Improving Students' Vocabulary Achievement through Word Wall Strategy. A Thesis for Faculty of Artsand Languages of State University of Medan. Unpublished

Arsyad, Azhar. 2013. Media Pembelajaran. Jakarta: PT Grafindo Persada

Asemota, Henry Erhamwenmwonyi. 2015. The Role of Media in English Language Development. International Journal of Humanities \& Social Science Studies (UHSSS). Vol 2.pp.311-316. 
Baidawi, Achmad. 2016. Using Visual Media in Teaching Speaking. Okara Journal of Languages and Literature, Vol. 1. Jakarta

Brown, Douglas. 2001. Language Assessment: Principles and Classroom Practices. New York: Longman.com

Borg \& Gall. 2003. Research and Development in Education. Cambridge: Cambridge University Press

Carol. Bertram.et al. 2010. Using Media in Teaching. Oxford: South African Institute for Distance Education.

Carr. J. U. Sexton, \& R Lagunoff. 2007. Making Science Accessible to English Learners: A Guide for Teachers. San Fransisco, CA: WestEd

Green, 1993. Teaching Vocabulary with Word Wall. New York

Harmer, Jeremy. 2001. How to Teach Writing. Essex: Pearson Education Limited

Harmer, Jeremy. 2004. The Practice of English Language Teaching. New York: Longman

Hutchinson, T. and Waters, A. 1987. English for Specific Purposes. Cambridge: Cambridge University Press.

Khotimah. 2015. The Effectiveness of Using Word Wall on Students' Matery in Vocabulary of Recount Text. "Holiday" at the Eight Hrade Studentsof Mts Khas Kempek. Kabupaten Cirebon. A Thesis for Vaculty of Tarbiyah and Teachers' of State Islamic University Syekh Nurjani Cirebon.unpublished.

Knapp, P.et al. 2005. Genre, Text Grammar: Technologies for teaching and Assesing Writing. Sydney: University of new South Wales Press Ltd

Kurniawan, Feri. 2016 The Use of Audio Visual Media in Teaching Speaking. English Education Journal (EEJ), 7(2), 180-193. University of Syiah Kuala, Banda Aceh

Mahajan, Gourav. 2012. "Multimedia in Teacher Education. Perceptions \& Uses".Journal of Education and Practice. Vol 3. (1),pp.5-14

Nadeem, et al. 2016. Students' Difficulties in Learning Writing Skills in Second Language.

Pardiyono. 2007. Pasti Bisa Teaching Genre-Based Writing Metode Mengajar Writing Berbasis Genre Secara Efektif. Andi Publisher

Tafari,Vilma.2009. “ Teaching English Through Mass Media”. Jounalof Acts Didactica Napocensia.Vol.2 (1).pp. 81-96.

Taiwo, Sunday. 2009. “Teachers' Perception of the Role of Mediain Classroom Teaching in Secondary Schools". Turkish Online Journalof Educational Technology (TOJET). Vol.8,pp. 75-83 
Zemach, D. E. \& Rumisek, L, A. 2005. Academic Writing from Paragraph to Essay, Macmillan: Cambridge University Press 